Correspondence to: MJ Goldacre michael.goldacre@ dphpc.ox.ac.uk incomplete measure of mortality even within 30 days of care. To identify the missing deaths, hospital statistical records need to be linked to data from death certificates. This is now feasible nationally in England.

Contributors: MJG designed the study and wrote the first draft of the paper. LG and MG built the linked files. MG and AM analysed the data. All authors contributed to later drafts of the paper. MJG and MG are the guarantors.

Funding: AM is funded by the Department of Health as part of its funding of the National Centre for Health Outcomes Development. The views expressed in this paper are those of the authors and not necessarily those of the Department of Health. The Unit of Health-Care Epidemiology is funded by the South East Regional Office of the NHS Executive.
Competing interests: None declared.

Department of Health and Social Security. Hospital activity analysis. London: DHSS, 1969.

2 Steering Group on Health Services Information. First report to the secretary of state. London: HMSO, 1982.

3 Acheson ED. Medical record linkage. Oxford: Oxford University Press, 1967.

4 Henderson J, Goldacre MJ, Simmons H, Griffith M. Recording of deaths in hospital information systems: implications for audit and outcome studies. J Epidemiol Community Health 1992;42:297-9.

5 Callum KG, Gray AJG, Hoile RW, Ingram GS, Martin IC, Sherry KM, et al. Then and now. The 2000 report of the National Confidential Enquiry into Perioperative Deaths. London: National CEPOD, 2000.

(Accepted 15 October 2001)

\title{
Preventing deaths by drowning in children in the United Kingdom: have we made progress in 10 years? Population based incidence study
}

Jo R Sibert, Ronan A Lyons, Beverley A Smith, Peter Cornall, Valerie Sumner, Maxine A Craven, Alison M Kemp, on behalf of the Safe Water Information Monitor Collaboration

Editorial by Brenner

Departments of Child Health and

Epidemiology

Statistics and Public

Health,

Collaboration for

Accident

Prevention and

Injury Control,

University of Wales

College of

Medicine,

Llandough

Hospital, Penarth

CF64 2XX

Jo R Sibert

professor of

community child

health

Ronan A Lyons

professor of public

health

Beverley A Smith

research nurse

Alison M Kemp

senior lecturer

Royal Society for

Prevention of

Accidents,

Birmingham

B5 7ST

Peter Cornall

head of water and

leisure

Maxine A Craven

research manager

continued over

BMJ 2002;324:1070-1
Detailed information on drowning in children is not routinely collected by offices of national statistics. Few studies have been carried out in the United Kingdom, and none has been done on British children abroad.

In 1988-9, two of the authors (AMK and JRS) combined information from national statistical offices, police forces (Royal Life Saving Society), and from a press cutting service (Royal Society for Prevention of Accidents) for a detailed analysis of deaths by drowning in children. ${ }^{1-3}$ This analysis found that 149 children had drowned in the United Kingdom during 1998-9. It also identified a safety agenda, which focused on young children in garden ponds and pools and on older children swimming without supervision.

Over the past 10 years there have been initiatives on children's safety in water, particularly swimming. We obtained similar information for 1998-9 to identify changes that have occurred in 10 years and assessed whether these initiatives on safety have been successful.

\section{Methods and results}

Deaths by drowning in children aged 0-14 years were identified in the same way in 1988-9 and 1998-9. We compared numbers of cases of drowning in the two periods by calculating the observed and expected numbers and comparing them with the expected numbers taken from the observed numbers in 1988, adjusted for the $6 \%$ increase in the child population over the 10 year period (table). We used the statistical package Confidence Interval Analysis to calculate ratios and 95\% confidence intervals. We identified deaths by drowning that occurred outside the United Kingdom from the Royal Society for Prevention of Accidents' survey of press cuttings.

A total of 104 children drowned in the United Kingdom in 1998-9 compared with 149 in 1988-9; this represents a significant fall in incidence. The numbers of children drowning fell in all sites, apart from deaths in garden ponds, where the numbers rose significantly $(\mathrm{P}<0.05)$. The decreases in drownings in three areas

Drownings in children aged 0-14 years in the United Kingdom

\begin{tabular}{|c|c|c|c|c|}
\hline \multirow[b]{2}{*}{ Location of drownings } & \multirow{2}{*}{$\begin{array}{c}1988-9 \\
\text { Observed }\end{array}$} & \multicolumn{2}{|c|}{$1998-9$} & \multirow[b]{2}{*}{ Ratio (95\% CI) } \\
\hline & & Expected & Observed & \\
\hline Bath & 25 & 23.58 & 25 & 1.06 (0.69 to 1.57$)$ \\
\hline Garden pond & 11 & 10.37 & 21 & $2.03(1.25 \text { to } 3.10)^{\star}$ \\
\hline Domestic pool & 18 & 16.97 & 4 & $0.24(0.06 \text { to } 0.60)^{\star}$ \\
\hline Private pool & 8 & 7.54 & 5 & 0.66 (0.21 to 1.55$)$ \\
\hline River, canal, lake & 56 & 52.81 & 31 & $0.59(0.40 \text { to } 0.83)^{\star}$ \\
\hline Public pool & 2 & 1.89 & 2 & 1.06 (0.13 to 3.82$)$ \\
\hline Sea & 20 & 18.70 & 10 & $0.53(0.26 \text { to } 0.98)^{\star}$ \\
\hline Other & 9 & 8.41 & 6 & 0.71 (0.26 to 1.55$)$ \\
\hline Total & $149 \dagger$ & 140.51 & $104 \ddagger$ & $0.74(0.61 \text { to } 0.90)^{\star}$ \\
\hline
\end{tabular}

${ }^{*} \mathrm{P}<0.05$

†111 boys, 38 girls.

$\ddagger 78$ boys, 26 girls. 
(rivers, canals, and lakes; domestic pools; and the sea) were also significant. Three times more boys than girls drowned during both periods (table).

At least 14 British children drowned abroad. Twelve of these drowned while swimming on holiday in Cyprus, France, Spain, Turkey, or the United States. Most of the drownings happened in hotel or apartment pools.

Three boys with autistic spectrum disorder drowned in 1998-9, compared with 0.1 cases expected from a recent study in the United Kingdom ${ }^{4}$ (the observed to expected ratio was $30(95 \%$ confidence interval 8.77, $\mathrm{P}<0.05)$ ).

\section{Comment}

The number of children dying from drowning in the United Kingdom has fallen over the 10 year period between 1988-9 and 1998-9. However, drownings in pools abroad and in garden ponds are a major concern, and safety organisations need to speak with holiday companies to improve the safety of children abroad. The European Union needs to be involved, and we believe that detailed data on deaths by drowning need to be collected routinely by government statistics offices in the United Kingdom.

The rise in the number of drownings in garden ponds may be due to an increase in the number of water features in gardens, perhaps as a result of popular garden programmes on television. Garden ponds remain a real threat to toddlers and should be covered or fenced. The reduction in drownings in domestic pools may be due to fewer pools being installed and used and some pools having safety fences and gates.

In the 10 years since 1998-9 there has been a focus on the supervision of activities with schoolchildren, and this is reflected by the reduction in river, lake, and canal drownings. The figures we have are small, but it does seem that children with autistic spectrum disorder may be at increased risk of drowning. This would coincide with their patterns of behaviour and needs further research.

We thank the Office for National Statistics (England and Wales) the Scottish Government Record Office, and the Northern Ireland Office for their invaluable help. This study was considered as Audit by the multi-centre research ethics committee for Wales.

Contributors: AMK and JRS undertook the study in 1988-9. JRS, AMK, MAC, PC, and VS planned the study and set up the SWIM Collaboration. JRS, BAS, MAC, PC, VS, and RAL analysed the data. JRS, RAL, BAS, and AMK wrote the paper. JRS is the guarantor.

Funding: No specific funding.

Competing interests: None declared.

1 Kemp AM, Sibert JR. Outcome for children who nearly drown: a British Isles study BMJ 1991:302:931-3.

2 Kemp AM, Sibert JR. Drowning and near drowning in children in the United Kingdom: lessons for prevention. BMJ 1992;304:1143-6.

3 Kemp A, Sibert JR. Epilepsy and the risk of drowning. Arch Dis Child 1993;68:684-5

4 Webb EV, Lobo S, Hervas A, Scourfield J, Fraser WI. The changing prevalence of autistic disorder in a Welsh health district. Dev Med Child Neurol 1997;39:150-2.

(Accepted 13 September 2001)

\section{Father of all bias?}

The minimisation of bias, the systematic deviation of results or inferences from truth, is a fundamental principle of medical research. ${ }^{1}$ Special care is taken by researchers to avoid and control for the 56 distinct types of bias catalogued. ${ }^{2}$ Yet the origin of the term "bias" remains obscure. ${ }^{3}$ Might it have originated from Bias of Priene, who lived in the 6th century вс?

Bias of Priene was one of the seven sages of classical antiquity. These were the jet-setting academics of the ancient world, who were praised for their maxims and consulted for their wisdom. Bias was even nominated for an early equivalent of the Nobel prize, a bronze tripod awarded to the wisest man, although he refused to accept it, believing that the god Apollo was more deserving. ${ }^{4}$ His claim as the namesake of bias comes from an account by Herodotus. ${ }^{5}$

Like many wealthy men, Croesus, king of Lydia, wished to expand his sphere of influence. He consulted Bias about the best way to deploy warships against the Ionians of the Aegean islands. Bias wished to avoid bloodshed, and so he misled Croesus, falsely advising him that the Ionians were buying 10000 horses with which to make a pre-emptive strike against Croesus. Croesus believed Bias, cancelled his warship programme, and immediately began preparing a land campaign against the Ionians. Bias confessed to Croesus that he had lied and that the Ionians were also building warships. Croesus was pleased with the way that he had been deceived by Bias and made peace with the Ionians. ${ }^{4}$

Some of the maxims attributed to Bias by Diogenes Laertius are echoed in a modern list of biases in analytic research. ${ }^{2}{ }^{4}$ These include
- "Even chance brings abundance of wealth to many" (allocation bias)

- "Admit the existence of Gods" (apprehension bias)

- "If a man is unworthy, do not praise him because of his wealth" (obsequiousness bias)

- "Make wisdom your provision for the journey from youth to old age; for it is a more certain possession than all other possessions" (anticipation bias).

His apophthegm, or maxim by which he is remembered, is: "All men are bad"-an unambiguous example of selection bias.

Duncan Hunter assistant professor, Department of Community Health and Epidemiology, Queen's University, Kingston ON, Canada

1 Last JM, ed. A dictionary of epidemiology. 4th ed. Oxford: Oxford University Press, 2001.

2 Sackett DL. Bias in analytic research.J Chron Dis 1979;32:51.

3 The Oxford English dictionary. 2nd ed. Oxford: Clarendon Press, 1989.

4 Herodotus. The histories, book 1,[27]. Translated by Wakefield R. Oxford: Oxford University Press, 1998.

5 Diogenes Laertius. Lives of eminent philosophers. Translated by Hicks RD. London: Heinemann, 1972

We welcome articles up to 600 words on topics such as A memorable patient, A paper that changed my practice, My most unfortunate mistake, or any other piece conveying instruction, pathos, or humour. If possible the article should be supplied on a disk. Permission is needed from the patient or a relative if an identifiable patient is referred to.
Royal Life Saving Society, Broom, Warwickshire B50 4HN

Valerie Sumner life saving support officer

Correspondence to: J R Sibert sibert@cardiff.ac.uk 